\title{
Betegnelsen epileptiker bør unngås
}

\author{
Det er en uting å karakterisere folk ut fra hvilken sykdom de har. Personer med epilepsi bør ikke omtales \\ som epileptikere.
}

I mer enn 30 år som nevrolog ved vårt nasjonale epilepsisenter har jeg truffet mange flotte og reflekterte mennesker med epilepsi. Flere sier de vil ha seg frabedt å bli kalt epileptiker. Som én uttrykte det: «Epilepsi er noe jeg har, ikke noe jeg er.» En annen uttrykte det slik: «Hvis anfall kan sies å være en karakteregenskap, både håper og tror jeg at jeg har flere andre og mer positive egenskaper, og jeg finner det vanskelig å akseptere at jeg blir karakterisert bare på grunnlag av noen anfall jeg har av og til.»

\section{I fagfeltet er begrepet forlatt}

Ved epilepsisenteret respekterer vi dette og omtaler pasientgruppen konsekvent som personer med epilepsi. Dette synes nå å ha blitt allment akseptert i fagfeltet, også utenfor Norge. Like fullt ser jeg stadig epileptikerbegrepet blir brukt i dagspressen. Ja, faktisk brukes det også i vårt eget tidsskrift, sist i påskenummeret (1).

\section{Bare flisespikkeri?}

Noen vil kanskje si at dette er semantisk flisespikkeri. Da bør man huske at det fortsatt i 2013 oppleves som svært belastende å få en epilepsidiagnose. Ikke bare på grunn av de uforutsigbare anfallene, men også på grunn av folks uvitenhet og fordommer. En annen av mine pasienter uttrykte det slik: «Anfallene kan jeg alltids leve med, men folks reaksjoner på å høre at jeg har epilepsi, er langt verre.»

Å bli omtalt som epileptiker opplevde han som både nedverdigende og stigmatiserende.

\section{Bør diabetiker, astmatiker og revmatiker også bort?}

Begrepet «epileptiker» burde naturligvis ikke være mer negativt ladet enn for eksempel «diabetiker», «astmatiker» eller «revmatiker». Rent prinsipielt synes jeg imidlertid det er en uting å karakterisere folk ut fra deres sykdommer.

Dessuten er de nevnte sykdommene svært heterogene, med mange alvorlighetsgrader. $\mathrm{Og}$ - som tidligere påpekt $\mathrm{i}$ denne spalten en person med en funksjonshemning er ikke nødvendigvis funksjonshemmet (2).

\section{Ordet «handikap» bør også vrakes}

Vi kan trolig alle være mer bevisst vårt ordvalg. Enkelte ord og uttrykk kan, uten at

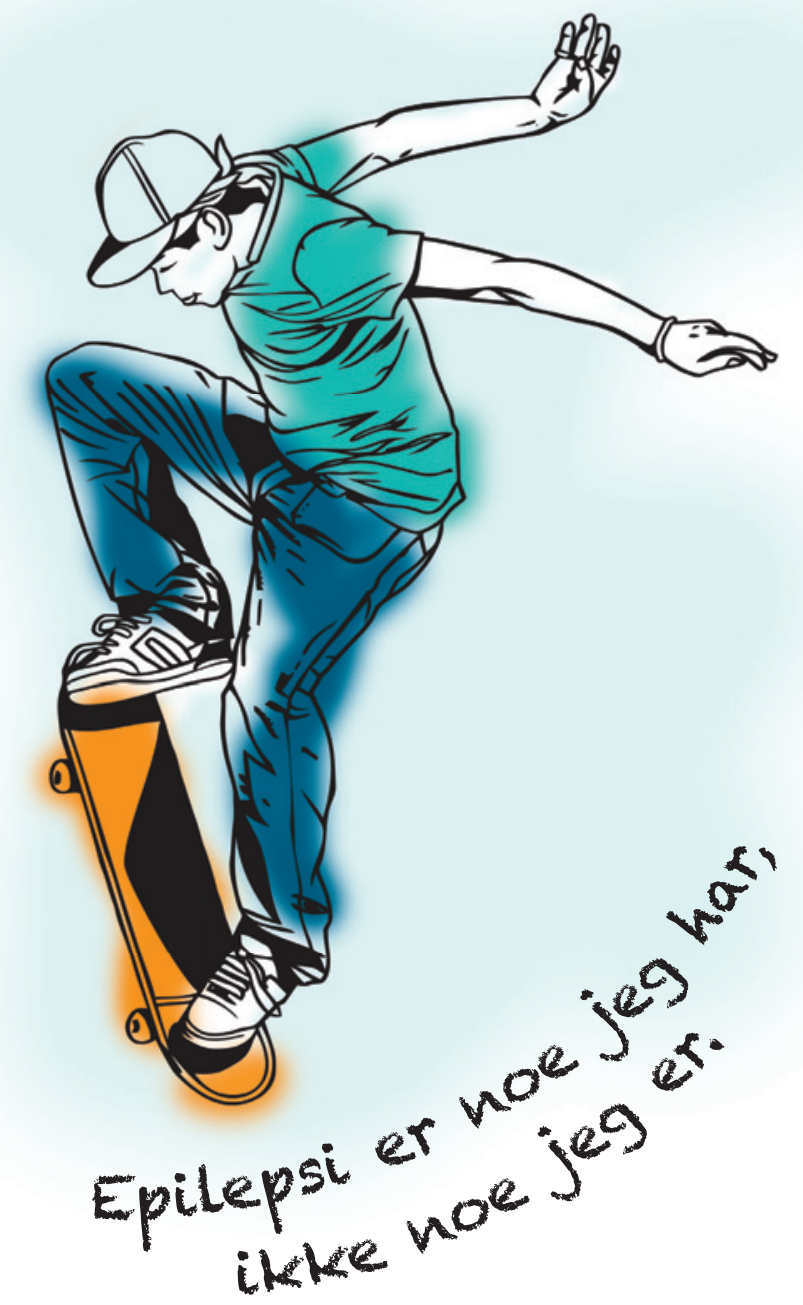

Illustrasjon Istockphoto

vi tenker over det, speile verdier og holdninger og som av og til virker støtende.

Tenk bare på ordet handikap. Det stammer fra en tid da folk med en funksjonssvikt sto med lua $\mathrm{i}$ hånda!

\section{Karl O. Nakken}

karl.otto.nakken@ous-hf.no

Karl Otto Nakken (f. 1945) er seksjonsoverlege ved Klinikk for kirurgi og nevrofag, Oslo universitetssykehus.
Litteratur

1. Brodwall K. Epilepsi i Afrika. Tidsskr Nor Legeforen 2013; 133: 631.

2. Nylund MF. Funksjonshemmet? Tidsskr Nor Legeforen 2009; 129: 1491

Mottatt 2.4. 2013, første revisjon innsendt 5.4 2013, godkjent 5.4. 2013. Medisinsk redaktør Raida Ødegaard. 